\title{
Platinum group elements geochemistry of ultramafic and associated rocks from Pindar in Madawara Igneous Complex, Bundelkhand massif, central India
}

\author{
V Balaram $^{1, *}$, S P Singh ${ }^{2}$, M Satyanarayanan ${ }^{1}$ and K V Anjaiah ${ }^{1}$ \\ ${ }^{1}$ National Geophysical Research Institute (Council of Scientific and Industrial Research), \\ Uppal Road, Hyderabad 500 007, India. \\ ${ }^{2}$ Department of Geology, Bundelkhand University, Jhansi 284001, India. \\ ${ }^{*}$ Corresponding author. e-mail: balaram1951@yahoo.com
}

\begin{abstract}
Ultramafic rocks comprising dunite, harzburgite, lherzolite, olivine webserite and websterite occur as intrusives in the form of small hillocks at Pindar into the granite-gneisses of Bundelkhand Gneissic Complex (BnGC). The peridotites are dominated by olivine cumulates where chromite and precious metal-bearing sulphides crystallized along with pyroxenes, subsequent to crystallization of olivine into the interstitial spaces of cumulates during cooling. Ultramafic rocks of Pindar are characterized by high $\mathrm{MgO}$ (up to 46.0 wt\%) and $\mathrm{FeO}$ (up to 5.8 wt\%); low $\mathrm{SiO}_{2}$ (40.8 to 48.0 wt\%), $\mathrm{TiO}_{2}$ (0.2 to 0.5 wt\%), $\mathrm{Al}_{2} \mathrm{O}_{3}$ ( $\sim 3.2 \mathrm{wt} \%$ av.), $\mathrm{CaO}(\sim 2.7 \mathrm{wt} \%$ av. $)$ and $\mathrm{Cu}(11$ to $73 \mu \mathrm{g} / \mathrm{g})$. Cr and Ni values range from 2297 to $3150 \mu \mathrm{g} / \mathrm{g}$ and 2434 to $2767 \mu \mathrm{g} / \mathrm{g}$, respectively. Distribution of $\operatorname{Ir}$ (up to $20 \mathrm{ng} / \mathrm{g}$ ), Ru (27 to $90 \mathrm{ng} / \mathrm{g}$ ), $\mathrm{Rh}(3$ to $14 \mathrm{ng} / \mathrm{g}$ ), Pt (18 to $72 \mathrm{ng} / \mathrm{g}$ ), $\mathrm{Pd}(10$ to $27 \mathrm{ng} / \mathrm{g}$ ) and $\mathrm{Au}$ (22 to $57 \mathrm{ng} / \mathrm{g}$ ) indicate platinum group element (PGE) and associated gold mineralization in these ultramafic rocks. A mineral phase representing sperrylite $\left(\mathrm{PtAs}_{2}\right)$ was also identified within the sulphides in scanning electron microscopy with energy dispersive spectrometer (SEM-EDS) studies. The primitive mantle-normalized siderophile elements pattern shows platinum group element PGE (PPGE) enrichment (Rh, Pt, Pd). Discrimination diagrams of $\mathrm{Pd} / \mathrm{Ir}$ vs. $\mathrm{Ni} / \mathrm{Cu}, \mathrm{Pd} / \mathrm{Pt}$ vs. $\mathrm{Ni} / \mathrm{Cu}, \mathrm{Cu} / \mathrm{Pd}$ vs. $\mathrm{Pd}$, and $\mathrm{Cu}$ vs. $\mathrm{Pd}$ for the peridotites of Pindar attribute to affinity towards komatiite magma, derived from high degree of partial melting of prolonged depleted mantle, and the sulphur saturation condition incurred during the crystallization of chromite which was favourable for PGE mineralization.
\end{abstract}

\section{Introduction}

The platinum group element (PGE: Ru, Rh, Pd, Os, Ir, Pt) abundances in crustal rocks that have formed from silicate melts and magmatic volatile phases, are widely studied to identify the fundamental geochemical controls of their formation and distribution in Earth's crust and to understand the characteristics of primary mantlederived magmatic processes (Brügmann et al. 1993; Rehkämper et al. 1999; Momme et al. 2002, 2003;
Crocket and Paul 2004; Qi and Zhou 2008; Balaram 2008; Song et al. 2009; Keays and Lightfoot 2010; Mondal 2011). The PGE geochemistry is also used in understanding the mechanism responsible for the $\mathrm{Ni}-\mathrm{Cu}$ and $\mathrm{PGE}$ deposits in different geological and tectonic settings ( $\mathrm{Li}$ and Ripley 2009; Naldrett 2010). The PGEs have been receiving considerable attention for a very long time - a couple of decades back, many attractive explorationtargets were identified because of advancement in the analytical technology and extensive utility in

Keywords. Platinum group elements; mineralization; ultramafic rocks; Pindar; Bundelkhand massif; central India. 
high technology applications. Hence, the discovery of new PGE deposits or mineralized zones is of great economic importance for the country's economic growth and development. PGE mineralization and related ore deposits are expected mainly in mafic igneous intrusions of different tectonic setting (Crocket and Paul 2004). The ultramafic complexes for PGE exploration have been broadly divided into two categories on the basis of their occurrences, viz., (i) PGE as by-product in massive deposit of $\mathrm{Ni}-\mathrm{Cu}$ (Kambalda type deposit) (Hudson et al. 1978; Lesher and Barnes 2009) and (ii) PGE deposits with $\mathrm{Ni}-\mathrm{Cu}$ as by-product (PGE reef type deposits, Maier et al. 1996; Maier 2005; Naldrett et al. 2009).

Exploration for PGE in India has been undertaken in several proposed prospective areas based on some fundamental genetic concepts of PGE mineralization in space and time. However, valuable occurrences of PGE in India are still very limited and have been reported from the plutonic to hypabyssal magmatic intrusions of ArchaeanPaleoproterozoic age, mostly emplaced into the Indian shield (Balaram 2008; Mukherjee 2010). Sukinda and Baula-Nausahi areas of Orissa in Singhbhum Craton (Auge et al. 2002; Mondal et al. 2007), Sittampundi area of Tamil Nadu in Southern Granulite Belt (Satyanarayanan et al. 2008, 2010b) and Hanumalapura area of Karnataka in Dharwar Craton (Devaraju et al. 2005; Alapieti et al. 2008) are the few important areas apart from some small locations (Mukherjee 2010; Nathan 2010; Dora et al. 2011). The presence of PGE in ultramafic terrain of Bundelkhand was reported by the Directorate of Geology and Mining, Uttar Pradesh (India) (Farooqui and Singh 2006). Subsequent to this report, they suggested presence of $10 \mathrm{~g} /$ ton of $\Sigma$ PGE (Farooqui and Singh 2010) in the ultramafic rocks of Ikauna. In the last couple of years, PGE mineralization has been identified by several workers from Madawara and Ikauna areas (Farooqui and Singh 2006; Singh et al. 2010a, 2010b; Satyanarayanan et al. 2010a, 2011). The ultramafic rocks of Pindar is a new location, which is nearly $15 \mathrm{~km}$ east of Madawara. This is an isolated body intrusive into the granite-gneisses of Bundelkhand massif for which our information is absolutely meagre. In the present paper, the geology and geochemical data of Pindar complex is being presented for the first time in view of the recent discovery of PGE in Bundelkhand massif.

\section{Geological setting}

The Bundelkhand massif is a prominent nucleus (figure 1) on the geological map of north-central India in the north of Son-Narmada lineament which is spread across 26,000 $\mathrm{km}^{2}$ (Basu 1986). The massif comprises mainly the granite-gneissic
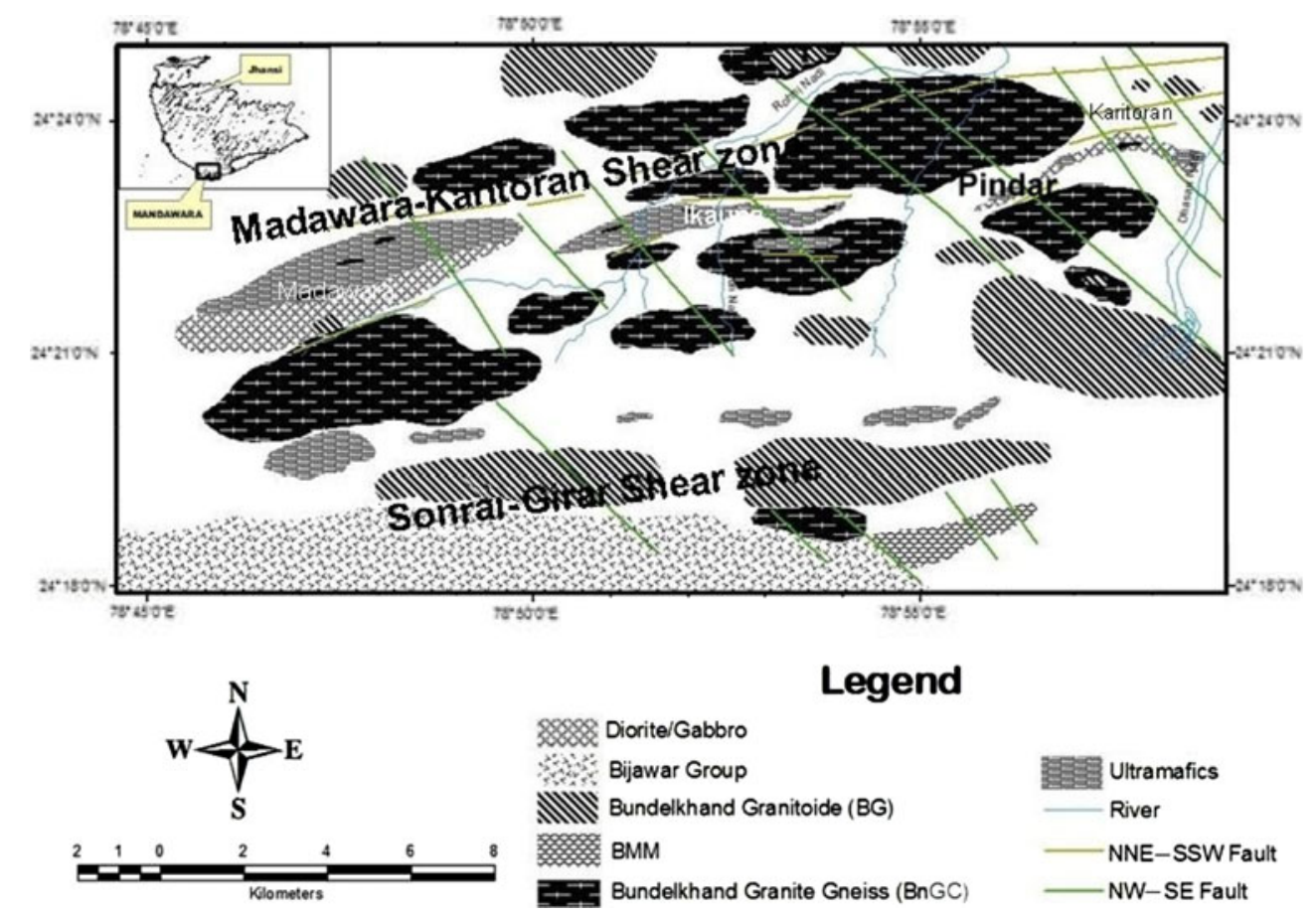

Figure 1. Geological map of Madawara Igneous Complex, central India showing lensoidal outcrop of ultramafic rocks into the granite-gneisses of BnGC. 
terrain of different episodes of Archean and Proterozoic rocks (Sharma 1982; Saha et al. 2011; Mondal et al. 2002). The mafic and ultramafic rocks, quartz reef and mafic dykes are present as intrusions in granite-gneisses and have been described from different parts of this craton (Sharma 1982; Basu 1986). A recent review on the geology of Bundelkhand massif (Singh et al. 2007) proposes five thermal events and two phases of metamorphism in the Archean. The oldest metamorphic event is demarcated by high grade metamorphism (amphibolite-granulite facies condition; Singh and Dwivedi 2009) from the Bundelkhand Gneissic Complex (BnGC) and the younger metamorphic event is low grade (Green schist facies conditions), recorded in Bundelkhand metasedimentary and metavolcanics (BnMM). The Madawara Ultramafic Complex is subsequent to the development of BnMM (Singh et al. 2010a, 2010b), which is mainly confined to southern part of the massif. The Bundelkhand Granitoid (BG) emplaced into the BnGC, BnMM and Madawara ultramafic complex has been considered to undergo the most pervasive magmatic activities and is marked as an event of rapid continental growth in the crust during the Late Archean (Mondal et al. 2002).

Ultramafic rocks in southern part of Bundelkhand massif are known from different places (Prakash et al. 1975; Basu 1986, 2010 and references therein). Sharma (1982) described the geological aspects of Madawara ultramafic rocks, while Basu (1986) encountered several shear fractures and dislocations in the ultramafic rocks at Gidwaha. However, the mineralogical and geochemical aspects of these ultramafic rocks were not much studied in view of mineralization. Farooqui and Singh (2006) and Singh et al. (2010a) mapped the ultramafic lenses around Madawara (figure 1) and also pointed out that these ultramafic rocks consist of high PGE values and appears to be a PGE mineralized zone in the Bundelkhand massif (Singh et al. 2010b). The geological map of southern part of the massif shows that ultramafic rocks and associated gabbro and diorite of Madawara ultramafic complex are confined between $\mathrm{E}-\mathrm{W}$ trending two shear zones, namely Karitoran-Madawara shear zone in north and Sonrai-Girar shear zone in south (figure 1), which are parallel to each other.

\section{Madawara ultramafic complex}

A series of $\mathrm{E}-\mathrm{W}$ trending ultramafic rocks are randomly exposed as lensoidal intrusive bodies in the form of isolated outcrops into the granitegneisses around Madawara (Singh et al. 2010b; Satyanarayanan et al. 2010a). These ulframafic rocks comprise mainly dunite, harzburgite, lherzolite, olvine websterite, orthpyroxenite and websterite. They are associated with medium-to-coarse grained gabbro and diorite. Sometimes, the lenses of ultramafic rocks are found in the diorites. Pindar area is about $15 \mathrm{~km}$ east of Madawara town where ultramafic rocks are exposed in the small hillocks (figure 1). The ultramafic rocks exposed here are $\mathrm{E}-\mathrm{W}$ trending and lensoidal in shape that is about $800 \mathrm{~m}$ in length and $200-300 \mathrm{~m}$ width. The contact between ultramafic rocks and granite-gneisses of BnGC is sharp, but in many places, sheared and mylonitized. The gabbro and diorites are mainly confined to the southern part of Pindar. The E-W trending ultramafic body of Pindar is also truncated by NW-SE trending Karitoran shear/faults which displaced these ultramafic rocks at several places.

The ultramafic rocks at Pindar are usually medium-to-coarse grained that consists of harzburgite, lherzolite, dunite and olvine websterite. However, the complex is dominated by peridotite rocks (figure 2a). The olivine websterite is dark bluish grey coloured, hard and compact, characterized by coarse grained cumulates of olivine and often found as intrusions into peridotite. They occur as small to giant size lenses (up to $8-10 \mathrm{~m}$ in length and
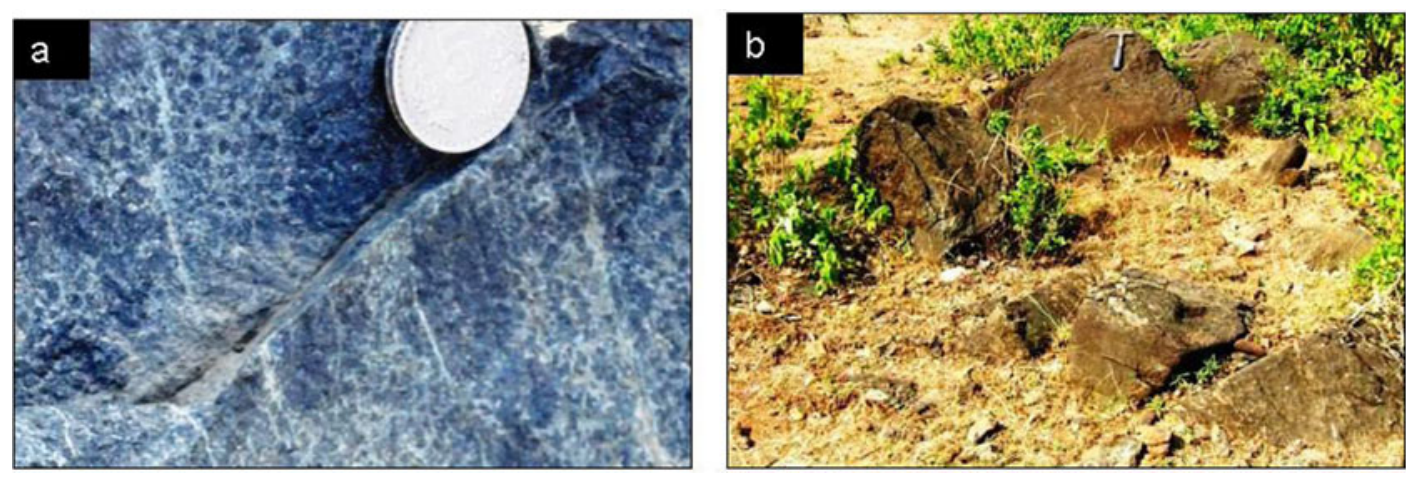

Figure 2. Field photographs showing (a) close up of peridotite and (b) part of the outcrop of ultramafic lenses at Pindar. 
4-5 $\mathrm{m}$ in width). The contact of these lenses with peridotites is usually crushed, altered, and sometimes sheared and mylonitized. Talc-chlorite schist is seen along the sheared contact. The olivine websterite and websterite are sometimes found as a disseminated body within the peridotite and its orientation is also parallel to the main ultramafic complex.

Mineralogically, olivine is the primary mineral of these ultramafic rocks, which is medium-to-coarse grained, free from inclusions, rimmed by pyroxenes (figure 3a). The intergranular space of the olivine cumulates are either occupied by orthopyroxene or clinopyroxene with chromite (figure $3 \mathrm{~b}, \mathrm{c}$ ). The medium-to-coarse grained, pyrrhotite and magnetite occur in intergranular spaces of cumulates (figure $3 \mathrm{~b}, \mathrm{~d}$ ) or along the cleavages of clinopyroxene. The sulphide-bearing phases, viz., pentlandite, pyrrhotite, chalcopyrite, and platinum group minerals (PGM), which were identified by SEM-EDS, occur as accessory fine-grained disseminated crystal into intergranular spaces of olivine or along the cleavages of pyroxenes (figure $3 \mathrm{~b}$ ). The alteration of olivine, pseudomorphic texture, appearance of talc-chlorite and serpentine is common. Plagioclase and amphiboles (hornblende) are nearly absent in the ultramafic rocks of Pindar and are found to be associated with gabbro and diorite.

\section{Geochemistry}

\subsection{Analytical methods}

Major and minor oxides $\left(\mathrm{SiO}_{2}, \mathrm{TiO}_{2}, \mathrm{Al}_{2} \mathrm{O}_{3}\right.$, $\mathrm{Fe}_{2} \mathrm{O}_{3}, \mathrm{MnO}, \mathrm{MgO}, \mathrm{CaO}, \mathrm{Na}_{2} \mathrm{O}, \mathrm{K}_{2} \mathrm{O}$ and $\mathrm{P}_{2} \mathrm{O}_{5}$ ) were determined in all the ultramafic samples by XRF (Philips ${ }^{\circledR}$ MagiXPRO-PW2440) at the CSIR-National Geophysical Research Institute, Hyderabad (India). International geochemical certified reference materials (CRM) from the US Geological Survey, the Canadian Geological Survey, the International Working Group (France) and NGRI (India) were used to prepare calibration curves for major oxides. Trace elements including rare earth elements (REE) and PGE were determined by ICP-MS (PerkinElmer SCIEX ELAN ${ }^{\circledR}$ DRC-II) at NGRI, Hyderabad (Balaram and Rao 2003). The analysis of PGE and Au was carried out by following NiS-fire assay method with Te co-precipitation and ICP-MS analysis described by Balaram et al. (2006). Single isotopes were used for all elements and selected based on their abundance levels and the freedom from interferences from other elements usually present in rock samples. The detection limits of most of the elements including PGE were about $0.01 \mathrm{ng} / \mathrm{ml}$, and the precision is better than $6 \% \mathrm{RSD}$ for trace and REE, and is $<10 \% \mathrm{RSD}$ for PGE data.
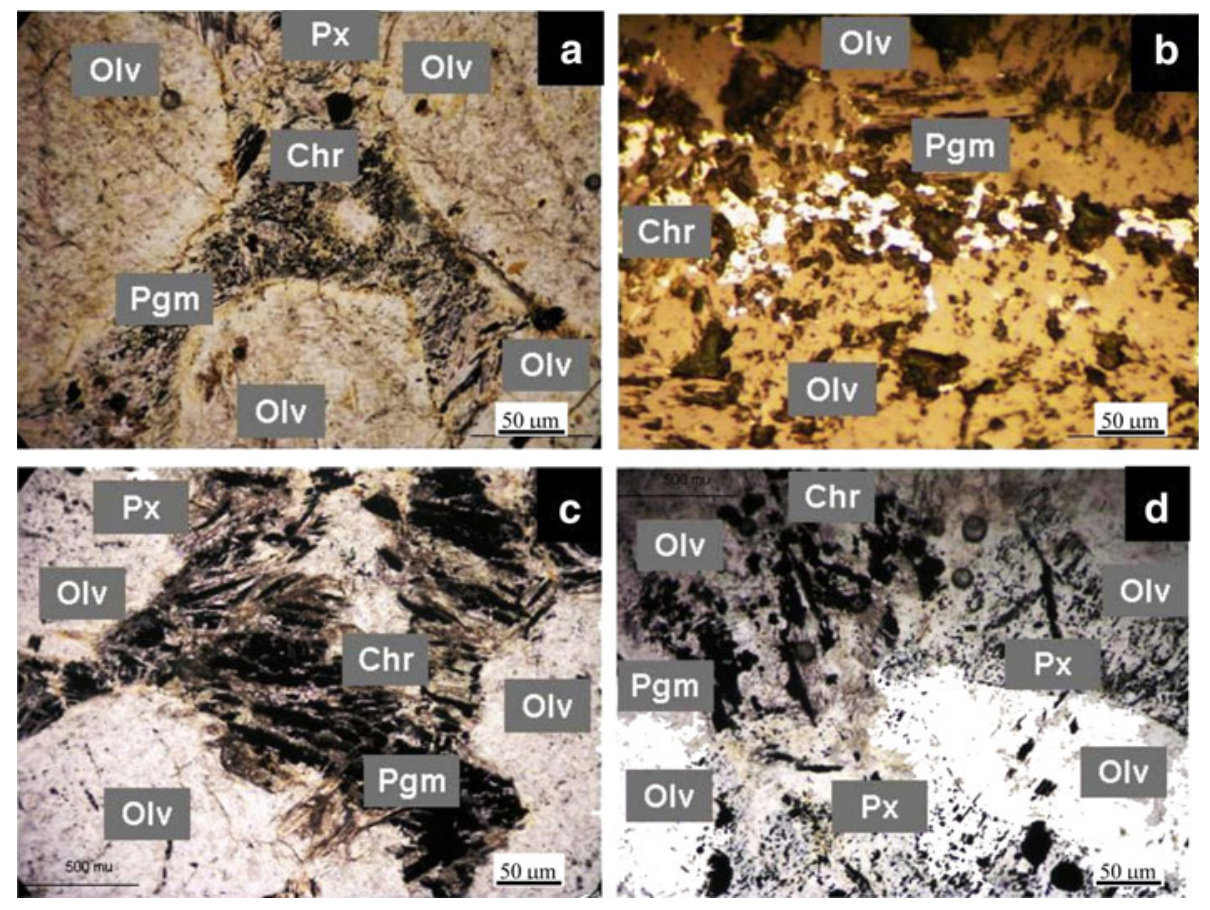

Figure 3. Photomicrographs showing (a) cumulates of olivine in which the intergranular spaces are filled by chromite (Cr), pyroxenes (Px) and sulphide-bearing minerals, (b) chromites and sulphide mineral including possible PGM present at the rim of olivine, (c) development of magnetites, pyroxenes and chromites in the intergranular spaces and (d) crystallization of magnetites, chromites and possible PGEs along the cleavages of pyroxenes and cracks of olivine. 
Table 1. Major oxides and trace elements (including REE and PGE) data of ultramafic rocks from Pindar (P), Madawara (MD) and Ikauna (I).

\begin{tabular}{|c|c|c|c|c|c|c|c|c|c|c|c|c|c|}
\hline Analyte & Unit & P-63 & P-64 & P-65 & P-66 & P-67 & P-68 & P-69 & P-70 & MD-12 & MD-20 & $\mathrm{I}-52$ & I-53 \\
\hline $\mathrm{SiO}_{2}$ & $\%$ & 40.8 & 41.7 & 41.0 & 40.1 & 41.8 & 42.8 & NA & 48.0 & 46.9 & 43.8 & 41.6 & 47.9 \\
\hline $\mathrm{Al}_{2} \mathrm{O}_{3}$ & $\%$ & 2.1 & 2.1 & 2.7 & 2.4 & 2.7 & 2.0 & NA & 8.3 & 1.0 & 0.8 & 3.0 & 5.6 \\
\hline $\mathrm{FeO}$ & $\%$ & 5.0 & 4.6 & 4.8 & 4.9 & 4.5 & 4.7 & NA & 3.5 & 10.4 & 10.5 & 5.0 & 4.5 \\
\hline $\mathrm{Fe}_{2} \mathrm{O}_{3} \mathrm{~T}$ & $\%$ & 6.5 & 6.0 & 6.2 & 6.4 & 5.8 & 6.2 & NA & 4.6 & 13.6 & 13.8 & 6.5 & 5.9 \\
\hline FeOT & $\%$ & 5.8 & 5.4 & 5.6 & 5.7 & 5.2 & 5.6 & NA & 4.1 & 12.2 & 12.4 & 5.8 & 5.3 \\
\hline $\mathrm{Fe}_{2} \mathrm{O}_{3}$ & $\%$ & 0.88 & 0.81 & 0.84 & 0.86 & 0.79 & 0.83 & NA & 0.62 & 1.84 & 1.86 & 0.88 & 0.80 \\
\hline $\mathrm{MnO}$ & $\%$ & 0.13 & 0.12 & 0.14 & 0.12 & 0.11 & 0.11 & NA & 0.09 & 0.14 & 0.14 & 0.13 & 0.19 \\
\hline $\mathrm{MgO}$ & $\%$ & 46.0 & 46.0 & 45.3 & 45.2 & 45.1 & 45.8 & NA & 28.7 & 30.0 & 35.2 & 45.3 & 31.0 \\
\hline $\mathrm{CaO}$ & $\%$ & 1.11 & 0.66 & 1.41 & 1.63 & 1.34 & 0.44 & NA & 12.02 & 3.59 & 0.08 & 0.99 & 6.86 \\
\hline $\mathrm{Na}_{2} \mathrm{O}$ & $\%$ & 0.05 & 0.06 & 0.11 & 0.04 & 0.06 & 0.03 & NA & 2.26 & 0.07 & 0.01 & 0.04 & 0.09 \\
\hline $\mathrm{K}_{2} \mathrm{O}$ & $\%$ & 0.03 & 0.03 & 0.03 & 0.03 & 0.04 & 0.02 & NA & 0.38 & 0.02 & 0.01 & 0.03 & 0.04 \\
\hline $\mathrm{TiO}_{2}$ & $\%$ & 0.2 & 0.2 & 0.2 & 0.2 & 0.2 & 0.2 & NA & 0.5 & 0.9 & 0.6 & 0.2 & 0.3 \\
\hline $\mathrm{P}_{2} \mathrm{O}_{5}$ & $\%$ & 0.02 & 0.02 & 0.02 & 0.02 & 0.20 & 0.02 & NA & 0.07 & 0.04 & 0.03 & 0.03 & 0.03 \\
\hline LOI & $\%$ & 4.0 & 4.1 & 3.7 & 4.7 & 3.2 & 3.0 & NA & 2.0 & 4.2 & 6.0 & 2.6 & 3.0 \\
\hline Sum & $\%$ & 100.9 & 100.9 & 100.8 & 100.7 & 100.5 & 100.5 & NA & 100.9 & 100.5 & 100.4 & 100.4 & 100.9 \\
\hline $\mathrm{Sc}$ & $\mu \mathrm{g} / \mathrm{g}$ & 10 & 10 & 12 & 11 & 12 & 11 & 10 & 19 & 17 & 13 & 11 & 14 \\
\hline $\mathrm{V}$ & $\mu \mathrm{g} / \mathrm{g}$ & 52 & 47 & 62 & 52 & 57 & 50 & 48 & 106 & 139 & 83 & 58 & 76 \\
\hline $\mathrm{Cr}$ & $\mu \mathrm{g} / \mathrm{g}$ & 2831 & 2703 & 3150 & 2297 & 2890 & 2721 & 2873 & 721 & 4454 & 4843 & 3898 & 2780 \\
\hline Co & $\mu \mathrm{g} / \mathrm{g}$ & 129 & 137 & 133 & 131 & 127 & 119 & 121 & 62 & 99 & 126 & 126 & 77 \\
\hline $\mathrm{Ni}$ & $\mu \mathrm{g} / \mathrm{g}$ & 2553 & 2655 & 2616 & 2434 & 2581 & 2466 & 2767 & 415 & 1358 & 1819 & 2413 & 1461 \\
\hline $\mathrm{Cu}$ & $\mu \mathrm{g} / \mathrm{g}$ & 19 & 11 & 16 & 25 & 11 & 63 & 14 & 73 & 38 & 29 & 25 & 14 \\
\hline $\mathrm{Zn}$ & $\mu \mathrm{g} / \mathrm{g}$ & 509 & 111 & 477 & 254 & 84 & 612 & 81 & 121 & 52 & 59 & 121 & 126 \\
\hline $\mathrm{Ga}$ & $\mu \mathrm{g} / \mathrm{g}$ & 5 & 4 & 5 & 4 & 5 & 5 & 4 & 18 & 8 & 4 & 5 & 8 \\
\hline $\mathrm{Rb}$ & $\mu \mathrm{g} / \mathrm{g}$ & 1 & 1 & 1 & 1 & 2 & 2 & 1 & 20 & 1 & 1 & 1 & 0 \\
\hline $\mathrm{Sr}$ & $\mu \mathrm{g} / \mathrm{g}$ & 7 & 5 & 19 & 5 & 5 & 9 & 7 & 202 & 27 & 5 & 5 & 8 \\
\hline $\mathrm{Y}$ & $\mu \mathrm{g} / \mathrm{g}$ & 4 & 3 & 4 & 4 & 4 & 4 & 3 & 7 & 7 & 3 & 4 & 5 \\
\hline $\mathrm{Zr}$ & $\mu \mathrm{g} / \mathrm{g}$ & 5 & 5 & 11 & 4 & 5 & 6 & 5 & 23 & 20 & 11 & 5 & 6 \\
\hline $\mathrm{Nb}$ & $\mu \mathrm{g} / \mathrm{g}$ & 0.1 & 0.1 & 0.1 & 0.04 & 0.1 & 0.1 & 0.1 & 0.4 & 0.6 & 0.4 & 0.1 & 0.1 \\
\hline Cs & $\mu \mathrm{g} / \mathrm{g}$ & 0.3 & 0.4 & 0.4 & 0.5 & 0.4 & 0.5 & 0.4 & 3.4 & 0.2 & 0.1 & 0.5 & 0.0 \\
\hline $\mathrm{Ba}$ & $\mu \mathrm{g} / \mathrm{g}$ & 2 & 2 & 3 & 3 & 5 & 8 & 2 & 17 & 84 & 15 & 5 & 2 \\
\hline $\mathrm{La}$ & $\mu \mathrm{g} / \mathrm{g}$ & 2.1 & 1.6 & 2.3 & 2.1 & 2.0 & 3.9 & 1.4 & 6.0 & 1.3 & 0.8 & 2.2 & 1.1 \\
\hline $\mathrm{Ce}$ & $\mu \mathrm{g} / \mathrm{g}$ & 4.4 & 3.3 & 4.4 & 3.9 & 4.0 & 8.2 & 3.0 & 12.1 & 5.0 & 2.9 & 4.5 & 3.2 \\
\hline $\operatorname{Pr}$ & $\mu \mathrm{g} / \mathrm{g}$ & 0.3 & 0.3 & 0.4 & 0.3 & 0.3 & 0.6 & 0.3 & 1.0 & 0.7 & 0.4 & 0.4 & 0.3 \\
\hline $\mathrm{Nd}$ & $\mu \mathrm{g} / \mathrm{g}$ & 1.7 & 1.3 & 1.9 & 1.5 & 1.7 & 2.8 & 1.4 & 5.3 & 3.1 & 1.7 & 1.9 & 2.0 \\
\hline $\mathrm{Sm}$ & $\mu \mathrm{g} / \mathrm{g}$ & 0.4 & 0.3 & 0.5 & 0.4 & 0.4 & 0.6 & 0.4 & 1.3 & 0.9 & 0.5 & 0.5 & 0.6 \\
\hline $\mathrm{Eu}$ & $\mu \mathrm{g} / \mathrm{g}$ & 0.1 & 0.1 & 0.2 & 0.1 & 0.1 & 0.1 & 0.1 & 0.5 & 0.2 & 0.03 & 0.1 & 0.1 \\
\hline Gd & $\mu \mathrm{g} / \mathrm{g}$ & 0.5 & 0.4 & 0.6 & 0.5 & 0.5 & 0.7 & 0.4 & 1.4 & 1.1 & 0.6 & 0.6 & 0.7 \\
\hline $\mathrm{Tb}$ & $\mu \mathrm{g} / \mathrm{g}$ & 0.1 & 0.1 & 0.1 & 0.1 & 0.1 & 0.1 & 0.1 & 0.2 & 0.2 & 0.1 & 0.1 & 0.1 \\
\hline Dy & $\mu \mathrm{g} / \mathrm{g}$ & 0.6 & 0.5 & 0.7 & 0.6 & 0.6 & 0.7 & 0.5 & 1.3 & 1.1 & 0.6 & 0.7 & 0.9 \\
\hline Ho & $\mu \mathrm{g} / \mathrm{g}$ & 0.1 & 0.1 & 0.2 & 0.1 & 0.1 & 0.2 & 0.1 & 0.3 & 0.3 & 0.1 & 0.1 & 0.2 \\
\hline Er & $\mu \mathrm{g} / \mathrm{g}$ & 0.4 & 0.3 & 0.5 & 0.4 & 0.4 & 0.5 & 0.4 & 0.8 & 0.8 & 0.4 & 0.4 & 0.6 \\
\hline $\mathrm{Tm}$ & $\mu \mathrm{g} / \mathrm{g}$ & 0.1 & 0.1 & 0.1 & 0.1 & 0.1 & 0.1 & 0.1 & 0.1 & 0.1 & 0.1 & 0.1 & 0.1 \\
\hline $\mathrm{Yb}$ & $\mu \mathrm{g} / \mathrm{g}$ & 0.3 & 0.3 & 0.4 & 0.4 & 0.4 & 0.4 & 0.3 & 0.7 & 0.7 & 0.4 & 0.4 & 0.5 \\
\hline $\mathrm{Lu}$ & $\mu \mathrm{g} / \mathrm{g}$ & 0.1 & 0.0 & 0.1 & 0.1 & 0.1 & 0.1 & 0.0 & 0.1 & 0.1 & 0.1 & 0.1 & 0.1 \\
\hline Hf & $\mu \mathrm{g} / \mathrm{g}$ & 0.1 & 0.1 & 0.3 & 0.1 & 0.1 & 0.1 & 0.1 & 0.4 & 0.4 & 0.2 & 0.1 & 0.1 \\
\hline $\mathrm{Ta}$ & $\mu \mathrm{g} / \mathrm{g}$ & 0.02 & 0.02 & 0.02 & 0.003 & 0.05 & 0.03 & 0.02 & 0.10 & 0.05 & 0.03 & 0.02 & 0.02 \\
\hline $\mathrm{Pb}$ & $\mu \mathrm{g} / \mathrm{g}$ & 12 & 12 & 12 & 11 & 8 & 23 & 9 & 10 & 12 & 10 & 13 & 9 \\
\hline Th & $\mu \mathrm{g} / \mathrm{g}$ & 0.1 & 0.1 & 0.1 & 0.1 & 0.1 & 0.2 & 0.1 & 0.3 & 0.3 & 0.3 & 0.1 & 0.1 \\
\hline $\mathrm{U}$ & $\mu \mathrm{g} / \mathrm{g}$ & 0.1 & 0.1 & 0.1 & 0.2 & 0.1 & 0.2 & 0.1 & 0.1 & 0.2 & 0.2 & 0.1 & 0.1 \\
\hline $\mathrm{Ru}$ & $\mathrm{ng} / \mathrm{g}$ & 90 & 42 & 49 & 59 & 67 & 52 & 54 & 27 & 82 & 78 & 61 & 57 \\
\hline $\mathrm{Rh}$ & $\mathrm{ng} / \mathrm{g}$ & 14 & 3 & 3 & 3 & 4 & 8 & 4 & 7 & 10 & 7 & 4 & 4 \\
\hline
\end{tabular}


Table 1. (Continued)

\begin{tabular}{|c|c|c|c|c|c|c|c|c|c|c|c|c|c|}
\hline Analyte & Unit & P-63 & P-64 & P-65 & P-66 & P-67 & P-68 & P-69 & P-70 & MD-12 & MD-20 & I-52 & $\mathrm{I}-53$ \\
\hline $\mathrm{Pd}$ & $\mathrm{ng} / \mathrm{g}$ & 17 & 14 & 11 & 10 & 15 & 14 & 22 & 27 & 87 & 37 & 19 & 53 \\
\hline $\mathrm{Ag}$ & $\mathrm{ng} / \mathrm{g}$ & 69 & 27 & 62 & 41 & 57 & 70 & 107 & 36 & 161 & 101 & 90 & 37 \\
\hline $\operatorname{Re}$ & $\mathrm{ng} / \mathrm{g}$ & 14 & 10 & 12 & 12 & 14 & 9 & 19 & 19 & 410 & 480 & 15 & 10 \\
\hline Os & $\mathrm{ng} / \mathrm{g}$ & 57 & 65 & 24 & 55 & 28 & 64 & 46 & 3 & 12 & 7 & 27 & 13 \\
\hline Ir & $\mathrm{ng} / \mathrm{g}$ & 20 & 10 & 12 & 13 & 15 & 13 & 13 & 2 & 12 & 18 & 15 & 9 \\
\hline $\mathrm{Pt}$ & $\mathrm{ng} / \mathrm{g}$ & 72 & 25 & 29 & 27 & 29 & 30 & 31 & 18 & 83 & 277 & 26 & 43 \\
\hline $\mathrm{Au}$ & $\mathrm{ng} / \mathrm{g}$ & 57 & 30 & 30 & 22 & 39 & 36 & 33 & 52 & 54 & 55 & 35 & 23 \\
\hline $\operatorname{PGE}(\mathrm{T})$ & $\mathrm{ng} / \mathrm{g}$ & 354 & 195 & 201 & 220 & 228 & 261 & 297 & 138 & 856 & 1004 & 257 & 227 \\
\hline
\end{tabular}

Table 2. Analytical data of geochemical standards WPR-1 and WMG-1. WPR-1 was used as calibration standard and WMG-1 was analysed as an unknown to check accuracy.

\begin{tabular}{|c|c|c|c|c|c|c|}
\hline \multirow[b]{2}{*}{ Analyte } & \multirow[b]{2}{*}{ Mass no. } & \multirow[b]{2}{*}{ Unit } & \multicolumn{2}{|c|}{ WPR-1 } & \multicolumn{2}{|c|}{ WMG-1 } \\
\hline & & & $\begin{array}{l}\text { Certified } \\
\text { value }\end{array}$ & $\begin{array}{c}\text { ICP-MS } \\
\text { Obtained value }\end{array}$ & $\begin{array}{l}\text { Certified } \\
\text { value }\end{array}$ & $\begin{array}{c}\text { ICP-MS } \\
\text { Obtained value }\end{array}$ \\
\hline $\mathrm{Ru}$ & 101 & $\mathrm{ng} / \mathrm{g}$ & 21.6 & $22.343 \pm 2$ & 27.6 & $35 \pm 2$ \\
\hline Rh & 103 & $\mathrm{ng} / \mathrm{g}$ & 13.4 & $13.067 \pm 1$ & 25.6 & $26 \pm 1.5$ \\
\hline $\mathrm{Pd}$ & 105 & $\mathrm{ng} / \mathrm{g}$ & 235.0 & $233.934 \pm 10$ & 307.8 & $382 \pm 18$ \\
\hline Os & 192 & $\mathrm{ng} / \mathrm{g}$ & 13.3 & $13.097 \pm 1.2$ & 14.6 & NA \\
\hline Ir & 193 & $\mathrm{ng} / \mathrm{g}$ & 13.5 & $13.671 \pm 1.5$ & 44.5 & $46 \pm 2$ \\
\hline $\mathrm{Pt}$ & 195 & $\mathrm{ng} / \mathrm{g}$ & 285.0 & $284.216 \pm 15$ & 892.0 & $861 \pm 41$ \\
\hline $\mathrm{Au}$ & 197 & $\mathrm{ng} / \mathrm{g}$ & 42.2 & $41.683 \pm 3$ & 82.4 & $102 \pm 5$ \\
\hline
\end{tabular}

\section{Results}

\subsection{Major, minor and trace elements}

The major and minor oxides and trace element compositions including REE and PGE of the ultramafic rocks of Pindar and adjoining areas are presented in table 1. The accuracy of PGE data has been validated by analysing an international geochemical CRM WMG-1 as an unknown sample, after calibrating the instrument with another CRM WPR-1 (table 2). The precision was evaluated by analysing three separate analyses of the CRM WMG-1, which was found to be $<10 \%$ RSD.

The rocks are characterized by high $\mathrm{MgO}$ (28.7 to $46.0 \mathrm{wt} \%), \mathrm{FeO}_{t}$ (4.1 to $\left.12.4 \mathrm{wt} \%\right)$ and low $\mathrm{Al}_{2} \mathrm{O}_{3}(\sim 2.3$ av. wt\%, except $8.3 \%$ for $\mathrm{P}-70), \mathrm{SiO}_{2}$ (40.1 to 48.0 wt\%) and $\mathrm{TiO}_{2}$ (0.2 to 0.9 wt\%). $\mathrm{Na}_{2} \mathrm{O}$ and $\mathrm{K}_{2} \mathrm{O}$ are extremely low and never exceeded 0.1 and $0.04 \mathrm{wt} \%$, respectively. Bivariate plots of $\mathrm{MgO}$ with $\mathrm{SiO}_{2}, \mathrm{CaO}$ and $\mathrm{Ni}$ show a distinct linear regression (either positive or negative slope) for the ultramafic rocks of Pindar and adjoining areas (viz., Madawara and Ikauna) (figure $4 \mathrm{a}-\mathrm{c}$ ). They tend to indicate an affinity towards fractional crystallization and their geochemical constituents correspond to very high $\mathrm{MgO}$ which is geochemically similar to komatiite composition. $\mathrm{MgO}$ : peridotite vs. $\Sigma \mathrm{PGE}$ and $\mathrm{Fe}_{2} \mathrm{O}_{3}$ vs. $\Sigma \mathrm{PGE}$ plots (figure 4d, e) show positive trend indicating primary magmatic affinity and enrichment of PGE in komatiite magma. The ultramafic rocks of Pindar are characterized by high $\mathrm{Ni}$ (2434 to $2767 \mu \mathrm{g} / \mathrm{g}$; excluding sample $\mathrm{P}-70), \mathrm{Cr}(2297$ to $3150 \mu \mathrm{g} / \mathrm{g}), \mathrm{Au}$ (22 to $57 \mu \mathrm{g} / \mathrm{g})$ and low $\mathrm{Cu}(<63 \mu \mathrm{g} / \mathrm{g})$, which are similar to that reported from Madawara ultramafic complex (Singh et al. 2010a, 2010b; Satyanarayanan et al. 2010a). The discrimination diagram of $(\mathrm{MgO}+\mathrm{FeO}) / \mathrm{TiO}_{2}$ vs. $\mathrm{SiO}_{2} /$ $\mathrm{TiO}_{2}$ (figure 4f) indicates distinct correlation, suggesting that the ultramafic rocks of Pindar are dominantly controlled by olivine crystallization.

Two distinct types of REE patterns, viz., with and without Eu negative anomaly (figure 5a) was observed with slight light rare earth elements (LREE) enrichment depicting the evolution of Pindar ultramafic complex initially through fractional crystallization. Primordial mantle normalized spider diagrams (Taylor and McLennan 1985) indicate 

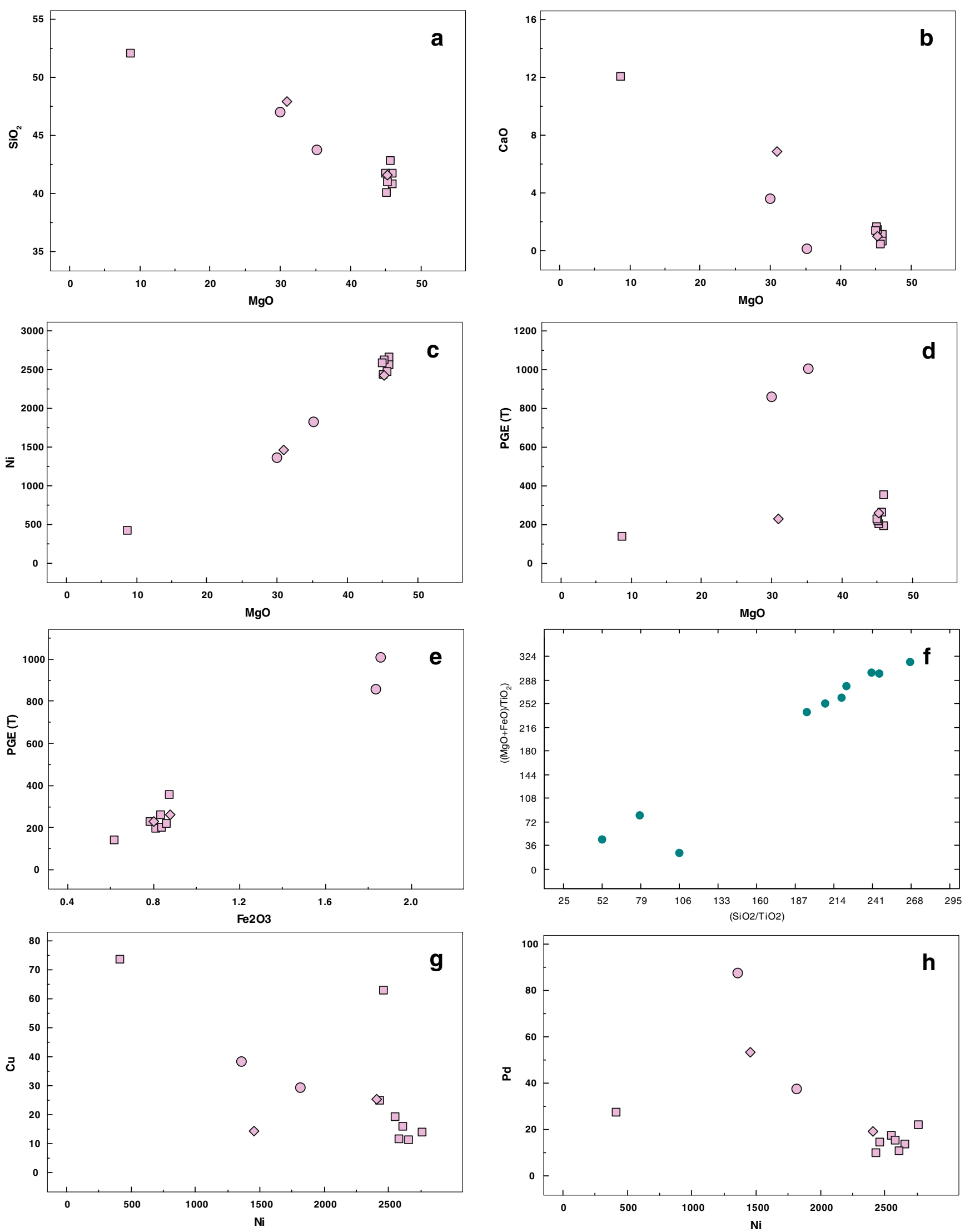

Figure 4. Bivariate plots of (a) $\mathrm{MgO}$ vs. $\mathrm{SiO}_{2}$, (b) $\mathrm{MgO}$ vs. $\mathrm{CaO}$, (c) $\mathrm{MgO}$ vs. $\mathrm{Ni}$, (d) $\mathrm{MgO}$ vs. total $\mathrm{PGE}$, (e) $\mathrm{Fe}_{2} \mathrm{O}_{3}$ vs. total PGE, (f) $\left(\mathrm{SiO}_{2} / \mathrm{TiO}_{2}\right)$ vs. $(\mathrm{MgO}+\mathrm{FeO}),(\mathrm{g}) \mathrm{Ni}$ vs. $\mathrm{Cu}$, and (h) Ni vs. Pd. Samples representing Pindar (square), Ikauna (diamond) and Madawara (circle) indicated in these plots represent the trend of crystallization. Major oxides are in wt\%, $\mathrm{Ni}$ and $\mathrm{Cu}$ in $\mu \mathrm{g} / \mathrm{g}$ and all PGE in $\mathrm{ng} / \mathrm{g}$. 

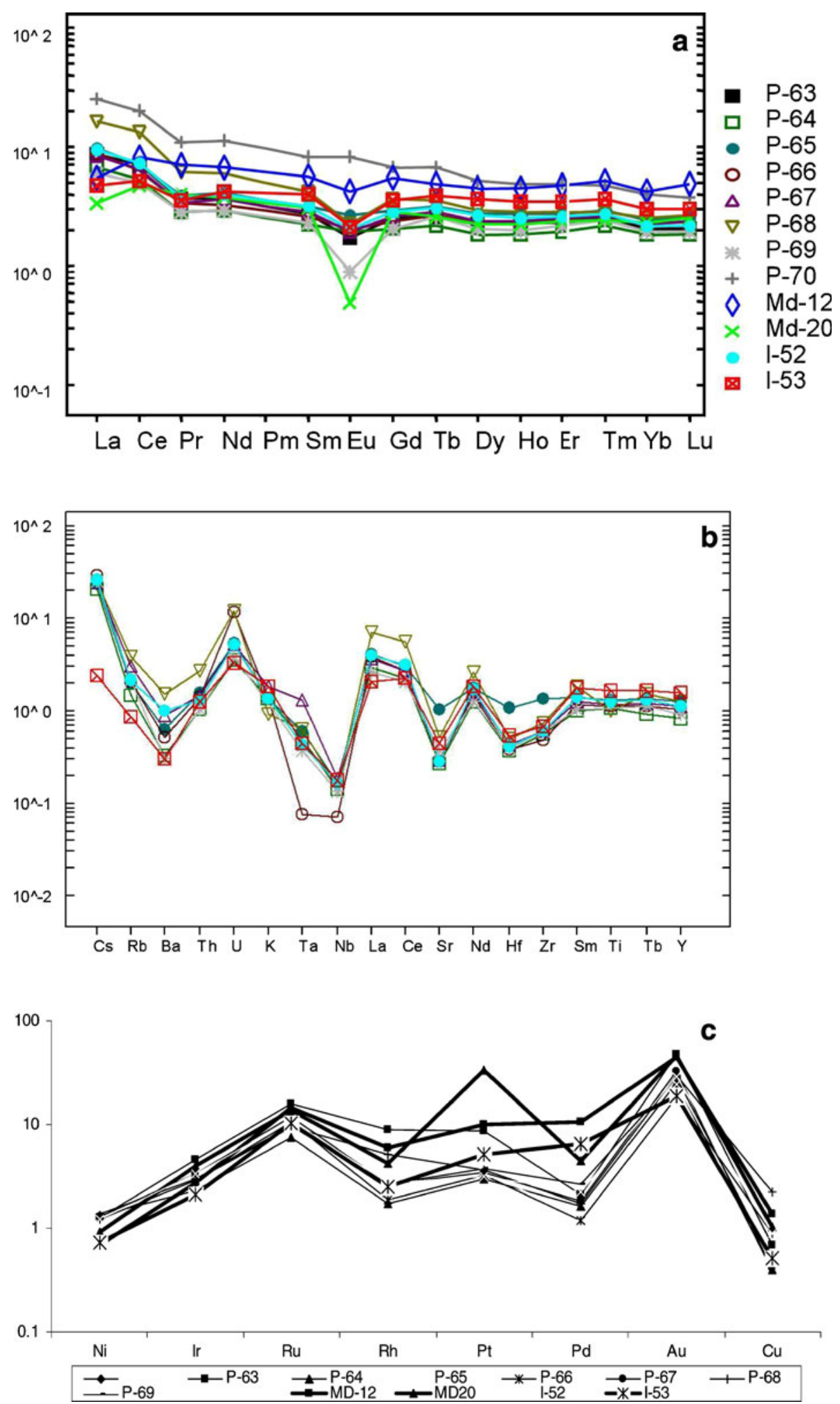

Figure 5. (a) Chondrite-normalized REE patterns of ultramafic rocks of Pindar, (b) trace elements spidergram and (c) PGE trend for the ultramafic rocks of Pindar and adjoining area showing Pt and Au-enriched trends.

depletion of high field strength elements (HFSE) (Sr, Ta, Nb, Rb, Y, Hf) and positive anomalies for Cs, La, Sm, U and Ti (figure 5b). In contrast to this, the enrichment of large-ion-lithophile elements (LILE) (Rb, K, U, Th) and depletion of HFSE (Nb, Hf, Zr and $\mathrm{Ba}$ ) were observed for those ultramafic rocks showing flat REE trend (without $\mathrm{Eu}$ anomaly). In general, rocks of $\mathrm{Eu}$ 
negative signature have more variation in the LILE and comprise pronounced negative anomalies of $\mathrm{Nb}$ and $\mathrm{Ta}$. The nature of these patterns suggests complex evolution of these ultramafic rocks through multiple magmatic processesssociated with crustal contamination in the magma in subsequent stages.

\subsection{PGE distribution trends in ultramafic rocks}

The ultramafic rocks of Pindar show $\Sigma$ PGE concentrations from 195 to $354 \mathrm{ng} / \mathrm{g}$ (table 1). Their Ir (10 to $20 \mathrm{ng} / \mathrm{g}$; excluding P-70), Ru (42 to $90 \mathrm{ng} / \mathrm{g}$ ), Rh (3 to $14 \mathrm{ng} / \mathrm{g}$ ), Pt (31 to $72 \mathrm{ng} / \mathrm{g}), \mathrm{Pd}$ (10 to $22 \mathrm{ng} / \mathrm{g}$ ) and $\mathrm{Au}$ (22 to $57 \mathrm{ng} / \mathrm{g}$ ) display relatively wide variations. $\mathrm{Pd} / \mathrm{Ir}$ ratios range from 0.52 to 5.14, whereas $\mathrm{Pd} / \mathrm{Pt}$ ratios vary from 0.11 to 1.0 . The bivariate plot of $\mathrm{Ni}$ with $\mathrm{Cu}$ and $\mathrm{Pd}$ shows a distinct negative correlation indicating normal cooling trend (figure $4 \mathrm{~g}, \mathrm{~h}$ ).

Naldrett et al. (1979) suggested that when chondrite-normalized PGE values are plotted in order of the descending melting point (Os, Ir, $\mathrm{Ru}, \mathrm{Rh}, \mathrm{Pt}, \mathrm{Pd}, \mathrm{Au}$ ), a smooth curve much similar to REE pattern will be obtained. These PGE curves usually provide valuable information about the fertile mantle, tectonic environment for magmatism, fractionation and contamination, fluidsulphide-silicate melt interactions during early history of magma (Barnes et al. 1985; Zhou et al. 2004; Mondal et al. 2007; Alapieti et al. 2008). The PGE trend (figure $5 \mathrm{c}$ ) of these ultramafic rocks suggest enrichment of Palladium group PGE (PPGE) (Rh, Pt, Pd) compared to Iridium group PGE (IPGE) (Ir and Ru).

\section{Discussion}

The behaviour of PGE abundances in ultramafic rocks and magmatic volatile phases are studied to identify the geochemical controls of their formation and distribution in Earth's crust, and to understand the primary mantle-derived magmatic processes (Peach and Mathez 1996). The olivine, chrome-spinel and sulphides of $\mathrm{Ni}, \mathrm{Fe}$ and $\mathrm{Cu}$ are the most compatible mineral phases for PGEenrichment in the ultramafic rocks (Keays et al. 1981; Crocket 2002), and are mainly responsible for PGE enrichment in the magmatic system. The five important factors, viz., (i) degree of partial melting of PGE-enriched/fertile mantle, (ii) metasomatism and fractionation of PGE-rich magma, (iii) dissolved sulphur (S) (iv) S-saturation condition during crystallization of magma, and (v) hydrothermal
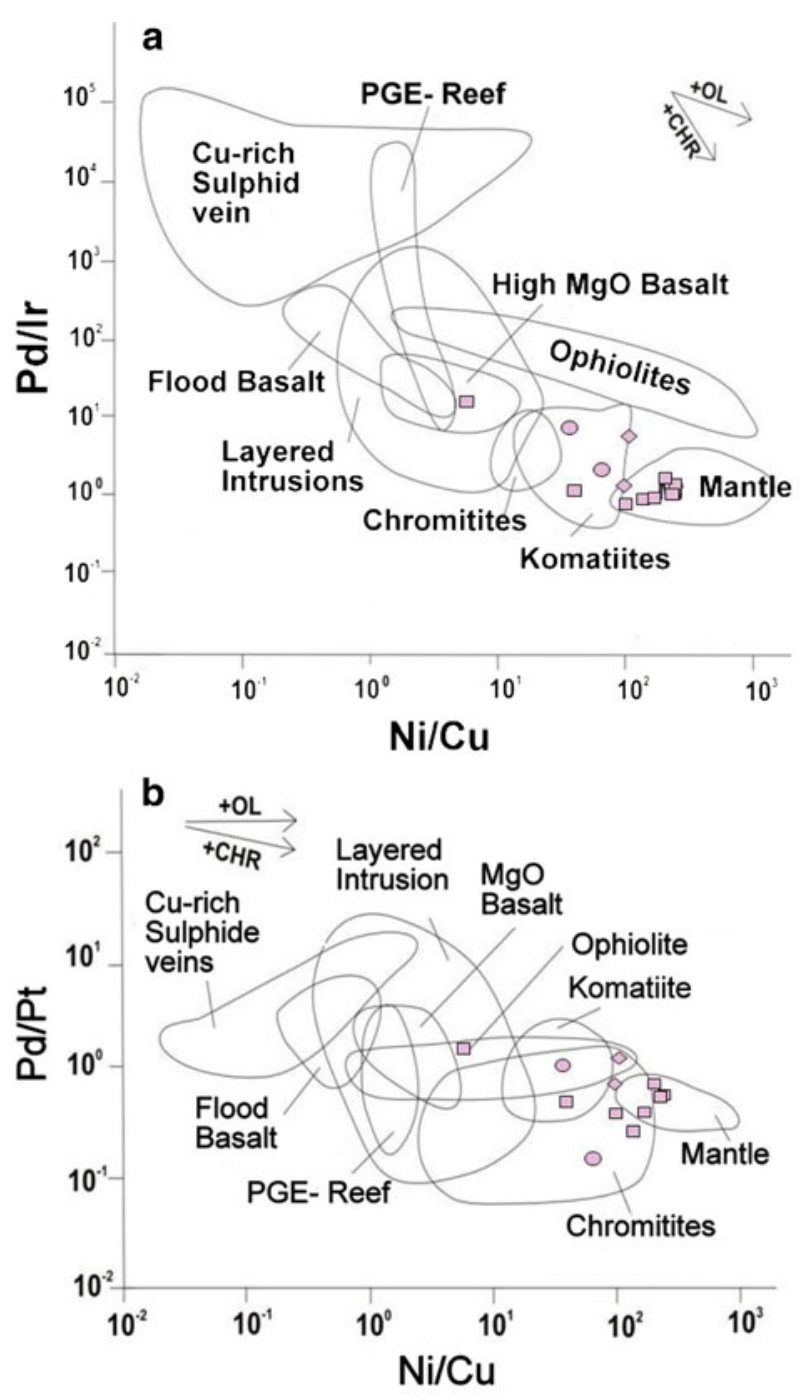

Figure 6. Classification diagram (Barnes et al. 1988) of (a) $\mathrm{Ni} / \mathrm{Cu}$ vs. $\mathrm{Pd} / \mathrm{Ir}$ and (b) Ni/Cu vs. Pd/Pt for ultramafic samples representing Pindar (square), Ikauna (diamond) and Madawara (circle) plotting in mantle to komatiite field.

intrusive, have been advocated for PGE deposits in many ultramafics and associated mafic rocks (Holwell and McDonald 2006; Maier 2005). They may work together or separately depending upon the prevailing geological conditions during emplacement (Naldrett 2010). However, among all these, the magmatic enrichment of PGE in ultramafic rocks are primarily controlled by the degree of partial melting of the juvenile mantle from which the mafic magma is derived.

High $\mathrm{MgO}, \mathrm{Ni}, \mathrm{Cr}$, Ir and low $\mathrm{V}, \mathrm{CaO}, \mathrm{Na}_{2} \mathrm{O}$, $\mathrm{Al}_{2} \mathrm{O}_{3}, \mathrm{~K}_{2} \mathrm{O}$ and $\mathrm{TiO}_{2}$ in the ultramafic rocks of Pindar suggest high degree of partial melting from the depleted mantle source, which prevailed during the development of peridotite-komatiite magma. The high $\mathrm{Ni} / \mathrm{Cu}$, low $\mathrm{Pd} / \mathrm{Ir}$ and $\mathrm{Pd} / \mathrm{Pt}$ ratios (figure $6 \mathrm{a}, \mathrm{b}$ ), and high concentration of IPGEs (table 1) from the study area compared 
to common ultramafic rocks indicates that ultramafic rocks of Pindar were formed during the Sunsaturated condition (Barnes and Picard 1993; Chen and Xia 2008). Presence of high $\mathrm{MgO}$ and higher PGE in these rocks view that the magma is derived from PGE-enriched fertile mantle. Observation about origin of ultramafic magma and various mechanisms for the fertility of juvenile mantle (Herzberg and O'Hara 1998; Sproule et al. 2002), and dissemination of sulphide within the ultramafic complex have been proposed from several areas (Barnes et al. 2004; Lesher and Barnes 2009) showing similar geochemical trend for the ultramafic rocks of Pindar. Linear sympathetic correlation of $\mathrm{MgO}$ vs. $\mathrm{Ni}$ and $\left(\mathrm{SiO}_{2} / \mathrm{TiO}_{2}\right)$ vs. $\left.(\mathrm{MgO}+\mathrm{FeO}) / \mathrm{TiO}_{2}\right)$ attributes the olivine and pyroxene crystallization trend in the magma in general.

Correlation between LREE and HREE ratios helps in distinguishing Al-depleted from Alundepleted komatiites. Al-depleted komatiites from the Barberton greenstone belt normally are moderately enriched in LREE and other incompatible trace elements, and have REE patterns that show a gentle increase (Gruau et al. 1990). Komatiites from the Pilbara Block, which, similar to Barberton, show depletion of both LREE and HREE, and have hump-shaped patterns. The REE abundance normalized to chondrite values of ultramafic rocks of Pindar show variable enrichments in LREE in general and is more or less uniform with flat trend of HREE; though, their Eu values and HFSE abundances differ from peridotite to pyroxenite. Two types of trends in trace elements distribution, viz. (i) depletion of HFSE ( $\mathrm{Sr}, \mathrm{Ta} \mathrm{Nb}, \mathrm{Rb}$, $\mathrm{Ba}, \mathrm{Y}, \mathrm{Hf}$ ) and positive anomalies of $\mathrm{Cs}, \mathrm{Nd}, \mathrm{Sm}$, $\mathrm{U}$ and $\mathrm{Ti}$ with $\mathrm{V}$-shaped strong negative anomaly of $\mathrm{Eu}$ in the harzburgites and lherzolites, and (ii) enrichment of LIL elements (Rb, K, Sr, U, Th) and depletion of $\mathrm{Nb}, \mathrm{Hf}, \mathrm{Zr}, \mathrm{Rb}$ in the olivine websterites and websterite (pyroxenites) have been also observed (figure 5b). Thus, enrichment in LILE associated with variable LREE enrichment from ultramafic rocks of Pindar could be the signature of some contamination or fractionation, which is presumed to have favoured PGE mineralization in the ultramafic rocks of Pindar. The processes of contamination and metasomatism in the magma for the PGM crystallization advocated from different ultramafic complexes (Sproule et al. 2002; Maier 2005; Chen and Xia 2008) suggests abundance of PGE subsequent to extraction of magma. Thus, the presence of high $\mathrm{MgO}$ and higher PGE from these ultramafic rocks and variations in geochemical (REE and PGE) trends suggest some contamination. If the significant enrichment in LILE associated with LREE and negative Eu anomaly for the rocks from Pindar is due to contamination or metasomatism, then the concentration of $\mathrm{Cu}$ and $\mathrm{Pd}$ should be higher as IPGE and $\mathrm{Rh}$ are mainly accommodated by MSS (monosulfide solid solution).

The segregation of sulphides and PGM from silicate melts is perhaps the most important aspect of $\mathrm{Cu}-\mathrm{Ni}-\mathrm{PGE}$ mineralization, on which several views have been proposed (Keays et al. 1981; Barnes et al. 2004). The rocks of Pindar show that coarse-grained olivine and pyroxenes are dominating minerals in these ultramafic rocks where the matrices or intergranular spaces of cumulates are occupied by medium-to-fine grained, grains of chromite (figure 3a, b). In websterites, most of the olivine has rim of pyroxenes. The rim of olivine and cleavages of pyroxenes in the websterites and olivine websterite are usually enriched by chromite, magnetite and sometimes with $\mathrm{Cr}$ spinels. Small crystals of Ni sulphides and PGM are present in disseminated form in the interstitial spaces of olivine cumulates and pyroxenes or cleavages of pyroxenes (figure $3 \mathrm{c}, \mathrm{d}$ ). The change in the texture from coarse-grained to fine-grained, and appearance of diverse mineralogy (oxides, sulphides and silicates) subsequent to the olivine crystallization/fractionation, is an important event in the ultramafic rocks at Pindar that could have provided a congenial environment for sulphur saturation conditions in the magma. Recent views (Lesher and Barnes 2009; Naldrett et al. 2009) suggest that timing of sulphur saturation condition is crucial to the crystallization of PGMs in the ultramafic rocks (Holwell and McDonald 2006). Crystallization of PGM progresses with different types of mineral paragenesis depending upon the prevailing sulphur saturation conditions in time and space (Naldrett 2010). For example, when sulphur saturation coincides with magnetite and chromite crystallization, IPGE concentrates in the chromite and pyrrhotite minerals. If sulphide saturation does not coincide with chromite crystallization, then Os, Ir and Rh may be present in chromite matrix and Pt, $\mathrm{Pd}$ and Rh will be absent, and subsequently PPGE mineral may occur in disseminated forms with Ni. If sulphide saturation occurs in the absence of or for prolonged period after chromite crystallization, PGE will associate with base metal sulphides. If sulphur saturation prevailed much before the chromite crystallization, PGE will be crystallized at greater depth and chromite may have poor values of PGE (Barnes 1990; Maier 2005). Removal of $\mathrm{FeO}$ phases, i.e., chromite, hercynite, chrome spinel, fayalite and magnetite, perhaps, promoted sulphur saturation in the system and favoured PGM and sulphide crystallization at Pindar. Similar conditions have also been described at several places in the Madawara ultramafic complex. 


\section{Conclusion}

The whole rock analyses for major, minor and trace elements (including REE and PGE) in the ultramafic rocks of Pindar area show high $\mathrm{MgO}, \mathrm{Ni}$, $\mathrm{Cr}, \mathrm{PGE}$ and extremely low in $\mathrm{Al}_{2} \mathrm{O}_{3}, \mathrm{CaO}, \mathrm{K}_{2} \mathrm{O}$, $\mathrm{TiO}_{2}$ and $\mathrm{V}$ contents. Extremely low abundances of HFSE, MREE, Zr, Y and high abundances of $\mathrm{Ni}, \mathrm{Co}, \mathrm{Nd}$ and Ir from the lherzolite, olivine websterite, dunite and harzburgite suggest high degree of partial melting, under S-undersaturated conditions from the juvenile mantle. The high $\mathrm{MgO}, \mathrm{Ni} / \mathrm{Cu}$ ratio, relatively low $\mathrm{Pd} / \mathrm{Ir}$ ratio and $\mathrm{Al}_{2} \mathrm{O}_{3}$ indicate komatiite-peridotite affinity for the source rock.

Petrographic study supported by geochemical data suggests that parent magma was enriched in PGE. The presence of granular aggregates of segregation of chromites, Ni sulphides and PGMs in the interstitial spaces of olivine cumulates, and along cleavages of pyroxenes is related to prevalence of S-saturation during cooling conditions. The presence of PGM in association with Fe-bearing phases (magnetite, pyrrhotite, chromite, etc.) or as disseminated sulphide minerals along with chromite indicate that $\mathrm{FeO}$-rich phases were perhaps triggering the crystallization of the sulphide-rich phases in the magma during the cooling. Nearly similar conditions for the appearance of PGM in the matrices of olivine cumulates have been proposed for the ultramafic rocks of Madawara.

\section{Acknowledgements}

The authors (VB, MS and KVA) are grateful to the CSIR - National Geophysical Research Institute, Hyderabad, for the support and permission to publish this paper. SPS is thankful to Ministry of Mines, Government of India, for providing financial support.

\section{References}

Alapieti T T, Devaraju T C and Kaukonen R J 2008 PGE mineralization in the late Archaean iron-rich maficultramafic Hanumalapur Complex, Karnataka, India; Mineral. Petrol. 92 99-128.

Auge T, Salpeteur I, Bailly L, Mukherjee M M and Patra R N 2002 Magmatic and hydrothermal platinum-group minerals and base-metal sulfides in the Baula complex, India; Canad. Mineral. 40 277-309.

Balaram V 2008 Recent advances in the determination of PGE in exploration studies - A review; J. Geol. Soc. India 72 661-677.

Balaram V and Rao T G 2003 Rapid determination of $\mathrm{REE}$ and other trace elements in geological samples by microwave acid digestion and ICP-MS; Atom. Spectrosc. $24206-212$.

Balaram V, Mathur R, Banakar V K, Hein J R, Rao C R M, Rao T G and Dasaram B 2006 Determination of the platinum group elements (PGE) and gold $(\mathrm{Au})$ in manganese nodule reference samples by nickel sulfide fire-assay and Te coprecipitation with ICP-MS; Indian J. Mar. Sci. 35 7-16.

Barnes S J 1990 The use of metal ratios in prospecting for a platinum-group element deposit; J. Explor. Geochem. 37 91-99.

Barnes S J and Picard C P 1993 The behaviour of platinumgroup elements during partial melting, crystal fractionation and sulphide segregation: An example from the Cape Smith Fold Belt, northern Quebec; Geochim. Cosmochim. Acta 57 79-87.

Barnes S J, Naldrett A J and Gorton M P 1985 The origin of the fractionation of the platinum-group elements in terrestrial magmas; Chem. Geol. 53 303-323.

Barnes S J, Hill R E T, Perring C S and Dowling S E 2004 Lithogeochemical exploration for komatiiteassociated Ni-sulfide deposits: Strategies and limitations; Mineral. Petrol. 82 259-293.

Basu A K 1986 Geology of parts of the Bundelkhand granite massif; Rec. Geol. Surv. India 117 61-124.

Basu A K 2010 Precambrian Geology of the Bundelkhand terrain, central India and adjacent part of western India; J. Econ. Geol. Georesour. Manag. 7 1-53.

Brügmann G E, Naldrett A J, Asif M, Lightfoot P C, Gorbachev N S and Fedorenko V A 1993 Siderophile and chalcophile metals as tracers of the evolution of the Siberian Trap in the Noril'sk region, Russia; Geochim. Cosmochim. Acta 57 2001-2018.

Chen G and Xia B 2008 Platinum-group elemental geochemistry of mafic and ultramafic rocks from the Xigaze ophiolite, southern Tibet; J. Asian Earth Sci. 32 406422.

Crocket J H 2002 Platinum-group element geochemistry of mafic and ultramafic rocks; In: Geology, geochemistry, mineralogy and mineral beneficiation of platinum-group elements (ed.) Cabri L J, Canadian Institute of Mining, Metallurgy and Petroleum, Special Volume 54 177-221.

Crocket J H and Paul D K 2004 Platinum-group elements in Deccan mafic rocks: A comparison of suites differentiated by Ir content; Chem. Geol. 208 273-291.

Devaraju T C, Alapieti T T and Kaukonen R J 2005 SEM-EDS study of the platinum-group minerals in the PGE mineralised Hanumalpura segment of layered maficultramafic complex of Channagiri, Davangere district, Karnataka; J. Geol. Soc. India 65 745-752.

Dora M L, Nair K K K and Shasidharan K 2011 Occurrence of platinum group minerals in the Western Bastar Craton, Chandrapur District, Maharashtra; Curr. Sci. 100 399-404.

Farooqui S A and Singh A K 2006 Platinum mineralization in Ikauna Area, Lalitpur District, Uttar Pradesh; J. Geol. Soc. India 68 582-584.

Farooqui S A and Singh P K 2010 PGE mineralisation in ultramafic/mafic enclaves of Ikauna area, Bundelkhand craton, India; In: Advances in Geosciences (ed.) Satake K, World Scientific Publishing Company, Solid Earth 20 111-120.

Gruau G, Chauvel, Arndt N T and Cornichet J 1990 Aluminum depletion in komatiites and garnet fractionation in the early Archean mantle: Hafnium isotopic constraints; Geochim. Cosmochim. Acta 54 3095-3101.

Herzberg C T and O'Hara M J 1998 Phase equilibrium constraints of the origin of basalts, picrites and komatiites; Earth Sci. Rev. 44 39-79.

Holwell D A and McDonald I 2006 Petrology, geochemistry and the mechanisms determining the distribution of platinum-group element and base metal sulphide mineralisation in the Platreef at Overysel, northern Bushveld Complex, South Africa; Mineral. Deposita 41 575-598.

Hudson D R, Robinson B W, Vigers R B W and Travis G A 1978 Zoned michenerite-testibiopalladite from Kambalda, Western Australia; Can. Mineral. 16 121-126. 
Keays R R, Ross J R and Woolrich P 1981 Precious metals in volcanic peridotite associated nickel sulfide deposits in Western Australia. II: Distribution within the ores and host rocks at Kambalda; Econ. Geol. 76 1645-1674.

Keays R R and Lightfoot P C 2010 Crustal sulfur is required to form magmatic $\mathrm{Ni}-\mathrm{Cu}$ sulfide deposits: Evidence from chalcophile element signatures of Siberian and Deccan Trap basalts; Mineral. Deposita 45 241-257.

Lesher C M and Barnes S J 2009 Komatiite-associated Ni$\mathrm{Cu}-(\mathrm{PGE})$ Deposits; In: Magmatic Ni-Cu-PGE deposits: Genetic models and exploration (eds) Li C and Ripley E M, Geological Publishing House of China, pp. 27-101.

Li C and Ripley E M 2009 New Developments in Magmatic $\mathrm{Ni}-\mathrm{Cu}$ and PGE Deposits; Geological Publishing House, Beijing, 290p.

Maier W D 2005 Platinum-group element deposits and occurrences: Mineralisation styles, genetic concepts, and exploration criteria; J. African Earth Sci. 41 165-191.

Maier W D, Barnes S J, Deklerk W J, Teigler B and Mitchell A A $1996 \mathrm{Cu} / \mathrm{Pd}$ and $\mathrm{Cu} / \mathrm{Pt}$ of silicate rocks in the Bushveld complex: Implications for platinum-group element exploration; Econ. Geol. 91 1151-1158.

Momme P, Tegner C, Brooks C K and Keays R R 2002 The behaviour of platinum-group elements in basalts from the East Greenland rifted margin; Contrib. Mineral. Petrol. $143133-153$.

Momme P, Óskarsson N and Keays R R 2003 Platinumgroup elements in the Icelandic rift system: Melting processes and mantle sources beneath Iceland; Chem. Geol. $196209-234$.

Mondal M E A, Goswami J N, Deomurari M P and Sharma K K 2002 Ion Microprobe ${ }^{207} \mathrm{~Pb} /{ }^{206} \mathrm{~Pb}$ ages of zircons from the Bundelkhand massif, northern India, implications for crustal evolution of the Bundelkhand-Aravalli protocontinent; Precamb. Res. 117 5-110.

Mondal S K 2011 Platinum Group Element (PGE) Geochemistry to understand the chemical evolution of the earth's mantle; J. Geol. Soc. India 77 295-302.

Mondal S K and Zhou M F 2010 Enrichment of PGE through interaction of evolved boninitic magmas with early formed cumulates in a gabbro-breccia zone of the Mesoarchean Nuasahi massif (eastern India); Mineral. Deposita 45 69-91.

Mondal S K, Frei R and Ripley E M 2007 Os isotope systematics of archean Chromite PGE deposits in the Singhbhum craton (India): Implication for the evolution of lithospheric mantle; Chem. Geol. 244 391-408.

Mukherjee M M 2010 Exploration for platinum group metals in India - A status note; Proc. Magmatic Ore Deposits, IMMT, Bhubaneshwar, 1-4 December 2009, http://www.geosocindia.org/Goldenjubilee/Fulltext_pdf/ MUKHERJEE\%20-\%20exploration.pdf.

Mukherjee R, Mondal S K, Rosing M T and Frei R 2010 Compositional variations in the Mesoarchean chromites of the Nuggihalli schist belt, Western Dharwar Craton (India): Potential parental melts and implications for tectonic setting; Contrib. Miniral. Petrol. $160865-$ 885.

Naldrett A J 2010 Secular variation of magmatic sulfide deposits and their source magmas; Econ. Geol. Spec. Issue $105669-688$.

Naldrett A J, Hoffman E L, Green A H, Chen L C and Naldrett S R 1979 The composition of Ni-sulfide ores, with particular reference to their content of PGE and $\mathrm{Au}$; Can. Mineral. 17 403-415.

Naldrett A J, Wilson A, Kinnaird J and Chunnett G 2009 PGE tenor and metal ratios within and below the Merensky Reef, Bushveld Complex: Implications for its genesis; J. Petrol. 50 625-659.
Nathan N P 2010 PGE Mineralisation in ultramafic-mafic complexes of Tamil Nadu: A preliminary note; J. Geol. Soc. India $\mathbf{7 6} 426$.

Peach C L and Mathez E A 1996 Constraints on the formation of platinum-group element depovsits in igneous rocks; Econ. Geol. 91 439-450.

Prakash R, Swarup P and Srivastava R N 1975 Geology and mineralization in the southern parts of Bundelkhand in Lalitpur district, Uttar Pradesh; J. Geol. Soc. India 16 $143-156$.

Qi L and Zhou M F 2008 Platinum-group elemental and Sr$\mathrm{Nd}-\mathrm{Os}$ isotopic geochemistry of Permian Emeishan flood basalts in Guizhou Province, SW China; Chem. Geol. 248 83-103.

Rehkämper M, Halliday A N, Fitton J G, Lee D C, Wieneke $\mathrm{M}$ and Arndt N T $1999 \mathrm{Ir}, \mathrm{Ru}, \mathrm{Pt}$ and Pd in basalts and komatiites: New constraints for the geochemical behavior of the platinum-group elements in the mantle; Geochim. Cosmochim. Acta 63 3915-3934.

Saha L, Pant N C, Pati J K, Berndt J, Bhattacharya A and Satynarayanan M 2011 Neoarchean high-pressure margarite-phengitic muscovite-chlorite corona mantled corundum in quartz-free high-Mg, Al phlogopitechlorite schists from the Bundelkhand craton, north central India; Contrib. Mineral. Petrol. 161 511530.

Satyanarayanan M, Subba Rao D V, Charan S N, Anbarasu K, Karthikeyan A, Narsing Rao S, Dasaram B, Sawant S S and Balaram V 2008 Petrological and geochemical characteristics of dunites and the associated granulites of Salem and Nagaramalai areas in Tamil Nadu, southern India; Indian Mineral. 42(1) 33-43.

Satyanarayanan M, Balaram V, Parijat R, Anjaiah K V and Singh S P 2010a Trace, REE and PGE geochemistry of the mafic and ultramafic rocks from Bundelkhand craton, central India; Adv. Geosci. 20 57-79.

Satyanarayanan M, Sylvester P J, Balaram V, Rao D V S, Charan S N, Tubrett M N, Shaffer M, Anbarasu K and Karthikeyan A 2010b PGE mineralization in the Late Archaean Sittampundi layered complex, southern India; In: Proc. 11th International Platinum Symposium, Sudbury, Canada (http://11ips.laurentian.ca/Laurentian/ Home/Departments/Earth+Sciences/NewsEvents/11IPS).

Satyanarayanan M, Balaram V, Singh S P, Sarma D S, Anjaiah K V and Aditya Kharia 2011 Platinum group elements in Madawara Igneous Complex, Bundelkhand massif, central India: Some exciting results; DCS-DST Newslett., January 2011, pp. 19-24.

Sharma R P 1982 Lithostratigraphy, structure and petrology of the Bundelkhand Group; In: Geology of Vindhyachal (eds) Valdiya K S, Bhatia S B and Gaur V K (New Delhi: Hindustan Publishing Corporation), pp. $30-46$.

Singh S P, Singh M M, Srivastava G S and Basu A K 2007 Crustal evolution in Bundelkhand area, central India; J. Himalayan Geol. 28 79-101.

Singh S P, and Dwivedi S B 2009 Garnet sillimanitecordierite-quartz bearing assemblages from the early Archean supracrustal rocks of Bundelkhand massif central India; Current Sci. 97 103-107.

Singh S P, Balaram V, Satyanarayanan M, Anjaiah K V and Kharya A 2010a Madawara Ultramafics Complex in Bundelkhand Craton: A new PGE repository for exploration in central India; J. Econ. Geol. Georesour. Manag. 7 51-68.

Singh S P, Balaram V, Satyanarayanan M, Anjaiah K V and Kharia A 2010b Platinum group elements in basic and ultrabasic rocks around Madawara, Bundelkhand massif, central India; Curr. Sci. 99 375-383. 
Song X Y, Keays R R, Xiao L, Qi H W and Ihlenfeld C 2009 Platinum-group element geochemistry of the continental flood basalts in the central Emeishan Large Igneous Province, SW China; Chem. Geol. 262 246-261.

Sproule R A, Lesher C M, Ayer J A and Thurston P C 2002 Komatiites and komatiitic basalts of the Abitibi greenstone belt: A proposed model for their formation; Precamb. Res. 115 153-186.
Taylor S R and McLennan S M 1985 The continental crust: Its composition and evolution (Oxford: Blackwell Scientific Publications), Geoscience Texts, $328 \mathrm{p}$.

Zhou M F, Robinson P T, Malpas J, Edwards S J and Qi L 2004 REE and PGE geochemical constraints on the formation of Dunites in the Luobusa ophiolite, southern Tibet; J. Petrol. 3 1-25.

MS received 22 July 2011; revised 7 July 2012; accepted 10 July 2012 